\title{
PERBANDINGAN SOLUSI NUMERIK INTEGRAL LIPAT DUA PADA FUNGSI ALJABAR DENGAN METODE ROMBERG DAN SIMULASI MONTE CARLO
}

\author{
Ermawati $^{\mathrm{i}}$, PujiRahayu ${ }^{\mathrm{ii}}$, Faihatus Zuhairoh ${ }^{\mathrm{iii}}$
}

\begin{abstract}
${ }^{i}$ Dosen Jurusan Matematika FST UIN Alauddin Makassar
ii Mahasiswa Jurusan Matematika FST UIN Alauddin Makassar

iii Dosen Jurusan Matematika YPUP
\end{abstract}

ABSTRAK, Integrasi numerik merupakan metode yang dapat digunakan untuk menyelesaikan persoalan integral yang sulit diselesaikan secara analitis. Artikel ini membahas tentang perbandingan tingkat keakuratan antara metode Romberg dan Simulasi Monte Carlo pada penyelesaian integral lipat dua untuk fungsi aljabar baik fungsi aljabar rasional maupun irrasional. Tingkat keakuratan dapat di ketahuin dari perbandingan galat antara kedua metode tersebut. Berdasarkan hasil simulasi pada beberapa fungsi aljabar baik rasional maupun irrasional menunjukkan bahwa nilai galat metode Romberg lebih kecil dibandingkan metode Simulasi Monte Carlo, meskipun jumlah iterasi untuk metode Simulasi Monte Carlo jauh lebih besar dibandingkan dengan metode Romberg. Sehingga dapat disimpulkan bahwa metode Romberg lebih akurat dibandingan dengan metode Simulasi Monte Carlo, pada penyelesaian integral lipat dua dengan fungsi aljabar baik yang rasional maupun irrasional.

Kata Kunci: Integrasi numerik, Galat, metode Romberg, Simulasi Monte Carlo

\section{PENDAHULUAN}

Perkembangan teknologi mempengaruhi berbagai segi kehidupan manusia yang dapat membawa perubahan pada bagaimana cara manusia menyelesaikan permasalahan yang dihadapi. Hadirnya pengaruh komputer membawa perkembangan yang terus berkelanjutan dalam melakukan pendekatan untuk menyelesaikan permasalahan yang dihadapi.

Banyak permasalahan yang dihadapi dapat dimodelkan ke dalam suatu persamaan integral. Namun persamaan integral ini terkadang bentuknya rumit sehingga sulit untuk diselesaikan dengan menggunakan kaidahkaidah kalkulus secara analitik. Untuk itu diperlukan bantuan komputer dan metode pendekatan yang tepat untuk dapat menyelesaikan persamaan tersebut secara efisien dan tepat. Untuk menangani pesamaan yang rumit dapat menggunakan metode numerik. Metode numerik merupakan teknik dimana masalah matematika diformulasikan sedemikian rupa sehingga dapat diselesaikan oleh pengoperasian matematika, dimana penggunaan metode ini menghasilkan solusi hampiran yang memang tidak persis sama dengan solusi yang sebenarnya (sejati). Akan tetapi tingkat keakuratannya dapat dilihat dari galat sekecil mungkin. Operasi hitungan dalam metode numerik umumnya dilakukan dengan iterasi sehingga jumlah hitungan yang dilakukan banyak dan berulang-ulang. Oleh karena itu diperlukan bantuan program aplikasi komputer untuk melaksakan operasi hitungan tersebut.

Metode numerik yang digunakan untuk memecahkan persoalan integral disebut integrasi numerik. Integrasi numerik merupakan suatu metode yang digunakan untuk mendapatkan nilai-nilai hampiran dari beberapa integral tentu yang memerlukan penyelesaian numerik sebagai hampirannya.

Penyelesaian integrasi dengan metode numerik terdiri dari tiga kelompok berdasarkan proses penurunannya yaitu metode pias, metode Gauss dan metode Newton-Cotes. Metode pias seperti metode trapesium, segi empat dan titik tengah. Metode Gauss seperti Gauss Legendre 2 titik, 3 titik dampai $n$ titik. Sedangkan metode NewtonCotes seperti metode trapesium, metode Simpson dan metode Boole. Metode Romberg merupakan gabungan dari rumus trapesium rekursif dan Boole Rekursif yang didasarkan pada perluasan ekstrapolasi Richardson sehingga dapat memperoleh nilai integrasi yang semakin baik. Selain itu, terdapat pula sebuah metode yang menggunakan pembangkit bilangan acak yang disebut Simulasi Monte Carlo. Walaupun menggunakan bilangan acak, metode Simulasi Monte Carlo mempunyai akurasi yang cukup tinggi karena berdasarkan pada teori probabilitas 
dan statistik. Masalah yang akan di bahas dalam artikel ini berkaitan dengan perbedaan tingkat keakuratan antara metode Romberg dan metode Simulasi Monte Carlo pada penyelesaian integral lipat dua pada fungsi aljabar, yang dimaksudkan untuk menjelaskan perbandingan tingkat keakuratan penggunaan metode Romberg dan Simulasi Monte Carlo dalam menyelesaian integral lipat dua pada fungsi aljabar.

\section{TINJAUAN PUSTAKA}

\section{Fungsi}

Suatu fungsi $f$ merupakan suatu aturan korespondensi yang menghubungkan setiap objek $x$ dalam suatu himpunan pertama dengan suatu nilai tunggal $f(x)$ dari suatu himpunan kedua.

Secara garis besar fungsi dibedakan menjadi dua yaitu fungsi aljabar dan fungsi transenden. Fungsi aljabar adalah fungsi yang diperoleh dari sejumlah berhingga operasi aljabar seperti penjumlahan, pengurangan, perkalian, pembagian, perpangkatan dan penarikan akar. Adapun yang termasuk fungsi aljabar adalah fungsi polynomial, fungsi rasional dan fungsi irasional.

\section{Integral}

Integral merupakan perhitungan kebalikan dari diferensial suatu fungsi (suatu fungsi asal yang diturunkan dapat kefungsi asalnya dengan cara integral). Integral terdiri dari integral taktentu (indefinite) dan integral tentu (definite).

Misalkan $f$ suatu fungsi yang didefinisikan pada interval tertutup $[a, b]$. Jika ada, maka dikatakan $f$ adalah terintegrasikan pada $[a, b]$.

Lebih lanjut

$\int_{a}^{b} f(x) d x$,

$$
\lim _{\|p\| \rightarrow 0} \sum_{i=1}^{n} f\left(\bar{x}_{i}\right) \Delta x_{i}
$$

disebut

Integral

tentu

(integral Riemann) $f$ dari $a$ ke $b$, kemudian diberikan oleh

$$
\int_{a}^{b} f(x) d x=\lim _{\|p\| \rightarrow 0} \sum_{i=1}^{n} f\left(\bar{x}_{i}\right) \Delta x_{i}
$$

Dalam bidang teknik, integral sering muncul dalam bentuk integral ganda dua (lipat dua) atau integral ganda tiga (lipat tiga). Integral lipat dua didefinisikan sebagai berikut:

$$
\begin{aligned}
\iint_{A} f(x, y) d A & =\int_{a}^{b}\left[\int_{c}^{d}(x, y) d y\right] d x \\
& =\int_{c}^{d}\left[\int_{a}^{b}(x, y) d x\right] d y
\end{aligned}
$$

\section{IntegrasiNumerik}

Integrasi numerik adalah suatu metode yang digunakan untuk mendapatkan nilai-nilai hampiran dari beberapa integral tentu yang memerlukan penyelesaian numeric sebagai hampirannya. Terdapat tiga pendekatan dalam menurunkan rumus integral numerik. Pendekatan pertama adalah berdasarkan tafsiran geometri integral tentu. Daerah integrasi dibagi atas sejumlah pias (strip) yang berbentuk segiempat. Luas daerah integrasi dihampiri dengan luas seluruh pias. Integrasi numerik yang diturunkan dengan pendekatan ini digolongkan kedalam metode pias. Kaidah integrasi numerik yang dapat diturunkan dengan metode pias adalah kaidah segiempat, kaidah trapezium dan kaidah titik tengah. Pendekatan kedua adalah berdasarkan interpolasi polinomial. Disini fungsi integran $f(x)$ dihampiri dengan polinomial interpolasi $p_{n}(x)$. Selanjutnya, integrasi dilakukan terhadap $p_{n}(x)$ karena polinom lebih mudah diintegralkan daripada mengintegralkan $f(x)$. Rumus integrasi numerik yang diturunkan dengan pendekatan ini digolongkan kedalam metode Newton-Cotes, yaitu metode umum untuk menurunkan rumus integrasi numerik. Adapun beberapa kaidah integrasi numerik yang diturunkan dari metode Newton-Cotes antara lain kaidah trapesium, kaidah Simpson $\frac{1}{3}$ dan kaidah Simpson $\frac{3}{8}$. Pendekatan ketiga sama sekali tidak menggunakan titik-titik diskrit sebagaimana pada kedua pendekatan di atas. Nilai integral diperoleh dengan mengevaluasi nilai fungsi pada sejumlah titik tertentu di dalam selang $[-1,1]$, mengalikannya dengan suatu konstanta, kemudian menjumlahkan keseluruhan perhitungan. Pendekatan ketiga ini dinamakan Kuadratur Gauss.

\section{Metode Romberg}

Metode Romberg merupakan metode integrasi yang didasarkan pada perluasan ekstrapolasi Richardson yang dihasilkan dari aturan trapesium rekursif. Kelemahan dari metode ini 
adalah harus menggunakan jumlah interval yang besar guna mencapai akurasi yang diharapkan. Salah satu cara untuk meningkatkan akurasi adalah dengan membagi dua interval secara terus menerus sampai nilai integral yang dihitung dengan $2^{\mathrm{k}}$ dan $2^{\mathrm{k}+1}$ konvergen pada suatu nilai. Proses penyelesaian integral dengan menggunakan metode Romberg dapat dilihat pada flow chart seperti pada gambar 1 berikut:

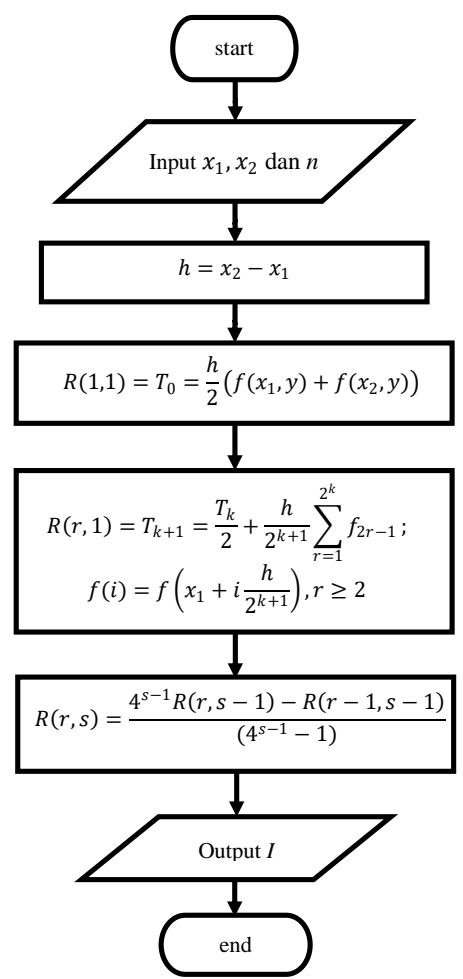

Gambar 1 Flowchart Penyelesaian Integral dengan Metode Romberg

\section{Simulasi Monte Carlo}

Metode simulasi Monte Carlo merupakan salah satu metode integrasi numerik dengan cara memasukkan sejumlah $\mathrm{N}$ nilai fungsi $x$ secara random dengan $x$ berada dalam interval integral, menurunkan secara acak nilai variabel tidak pasti secara berulang-ulang dalam simulasi model. Rumusan integrasi numerik dengan metode simulasi Monte Carlo adalah sebagai berikut:

$$
\int_{a}^{b} f(x) d x=\frac{b-a}{n} \sum_{i=1}^{n} f(x i)
$$

Dengan $x_{i}$ adalah bilangan random yang dibangkitkan dengan harga $a \leq x i \leq b$ dan $n$ adalah jumlah masukkan (pengulangan) banyak data yang diinginkan. Proses penyelesaian integral dengan menggunakan simulasi Monte
Carlo dapat dilihat pada flow chart seperti pada gambar 2 berikut:

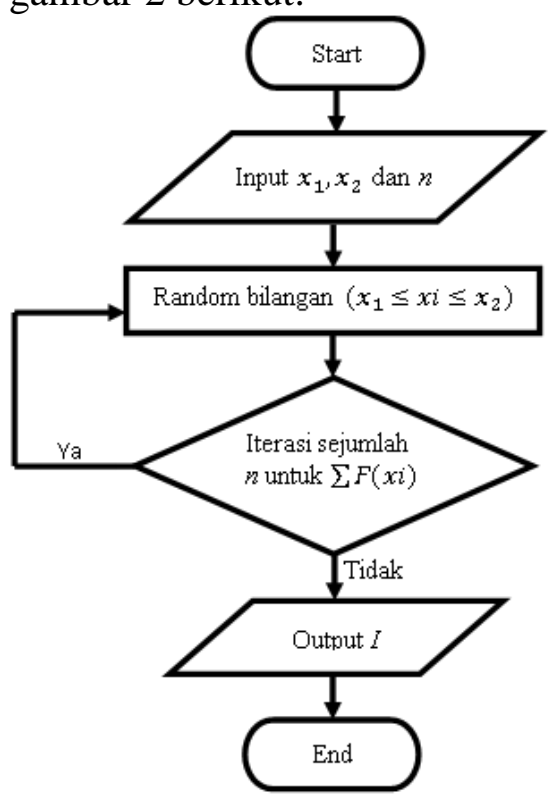

Gambar 2 Flow Chart Penyelesaian Integal dengan Simulasi Monte Carlo

\section{Galat}

Galat atau biasa disebut error dalam metode numerik adalah selisih antara yang ditimbulkan antara nilai sebenanrnya dengan nilai yang dihasilkan dengan metode numerik. Galat dibedakan menjadi tiga yaitu:

\section{Galat Mutlak}

Kesalahan mutlak dari suatu angka, pengukuran, atau perhitungan adalah perbedaan numerik nilai sesungguhnya terhadap nilai pendekatan yang diberikan, atau yang diperoleh dari hasil perhitungan atau pengukuran.

Kesalahan $($ Error $)=$ nilai Eksak - Nilai perkiraan Jika $a^{*}$ adalah hampiran dari nilai eksak a maka galat mutlak dari a adalah $E=\left|a-a^{*}\right|$ yang berarti hampiran $=$ nilai eksak - galat

2. Galat Relatif

$$
e=\frac{E}{A}=\frac{a-a^{*}}{a}=\frac{\text { Galat }}{\text { Nilai Eksak }}
$$

3. Persentase Galat

Persentase galat adalah 100 kali galat relatif

$$
\xi a=e^{*} 100 \%
$$




\section{METODOLOGI}

\section{Prosedur Analisis}

Adapun prosedur penelitian yang digunakan penulis untuk mencapai tujuan penelitian adalah sebagai berikut:

1. Memberikan contoh soal integral lipat dua dengan fungsi aljabar rasional untuk diselesaikan secara analitik,

2. Menyelesaikan contoh soal menggunakan metode Romberg dan Simulasi Monte Carlo secara numeric dengan iterasi $n=2$ dan $n=4$,

3. Menghitung galat dari masing-masing metode dan membandingkan hasilnya,

4. Mensimulasikan beberapa fungsi aljabar rasional dan irrasional pada program Matlab dengan menggunakan metode Romberg dan Simulasi Monte Carlo sesuai dengan flowchart pada BAB II,

5. Membandingkan hasil simulasi untuk $n=2$ dan $n=4$. Kemudian menganalisis galat mutlak dari kedua metode untuk mendapatkan metode yang paling akurat.

\section{PEMBAHASAN}

Diberikan contoh soal integral lipat dua sebagai berikut:

$$
\int_{0}^{2} \int_{0}^{1} \frac{x^{2} y}{x^{3}+1} d x d y
$$

\section{Penyelesaian secara Analitik}

Metode Substitusi:

Misal $u=x^{3}+1$

$$
\begin{aligned}
& d u=3 x^{2} d y \\
& \frac{1}{3} d u=x^{2} d y
\end{aligned}
$$

untuk batas $x=0=>u=0^{3}+1=1$, dan untuk batas $x=1=>u=1^{3}+1=2$

$$
\begin{aligned}
\int_{0}^{2} \int_{0}^{1} \frac{x^{2} y}{x^{3}+1} d x d y & =\int_{1}^{2} y \int_{1}^{2} \frac{1}{3 u} d u d y \\
& =\int_{0}^{2} \frac{1}{3} \ln 2 y d y \\
& =\frac{1}{6}\left[\ln 2 y^{2}\right]_{0}^{2} y^{2}
\end{aligned}
$$

$$
=\frac{4}{6} \ln 2
$$

Solusi di atas merupakan solusi eksak. Namun untuk menyelesaikan perhitungan secara numerik harus diubah dalam bentuk desimal untuk mendapatkan solusi hampiran. Oleh karena itu, nilai $\frac{4}{6} \ln 2$ jika diubah dalam bentuk desimal menjadi 0,46209812

\section{Penyelesaian Secara Numerik}

Dengan menggunakan 8 angka penting, hasil perhitungan numerik metode Romberg dan Simulasi Monte Carlo adalah sebagai berikut:

\section{Metode Romberg:}

1. Fungsi integran yang didefinisikan adalah $\frac{x^{2} y}{x^{3}+1}$

2. Batas bawah daerah integrasi $x_{1}=0$, batas atas daerah integrasi $x_{2}=1$

Batas bawah daerah integrasi $y_{1}=0$, batas atas daerah integrasi $y_{2}=2$

3. Untuk iterasi $\boldsymbol{n}=\mathbf{2}$ :

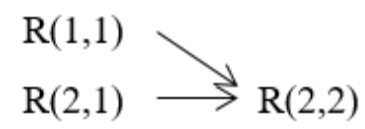

Integral pertama yang diselesaikan adalah integral terhadap $x$

a. Menentukan lebar interval $(h)$ pada batas $x$ :

$$
\begin{aligned}
h & =x_{2}-x_{1} \\
h & =1-0 \\
& =1
\end{aligned}
$$

b. Menghitung integrasi pada kolom pertama $R(1,1)$ :

$$
\begin{aligned}
R(1,1)=T_{0} & =\frac{h}{2}\left(f\left(x_{1}, y\right)+f\left(x_{2}, y\right)\right) \\
f\left(x_{1}, y\right) & =f(0, y)=f(0)=0 \\
f\left(x_{2}, y\right) & =f(1, y)=f(1)=\frac{1}{2} y \\
R(1,1)=T_{0} & =\frac{1}{2}\left(0+\frac{1}{2} y\right) \\
& =\frac{1}{4} y \\
& =0,25000000 y
\end{aligned}
$$

c. Menghitung integrasi pada baris kedua kolom pertama $R(2,1)$ :

$$
\begin{aligned}
R(r, 1)=T_{k+1} & =\frac{T_{k}}{2}+\frac{h}{2^{k+1}} \sum_{j=1}^{2^{k}} f_{2 j-1}, f_{i} \\
& =f\left(x_{1}+i \frac{h}{2^{k+1}}\right), r \geq 2
\end{aligned}
$$




$$
\begin{gathered}
R(2,1)=T_{1}=\frac{T_{0}}{2}+\frac{h}{2} f_{1} \\
f_{1}=f\left(x_{1}+\frac{h}{2}\right)=f\left(0+\frac{1}{2}\right)=f\left(\frac{1}{2}\right) \\
=\frac{\left(\frac{1}{2}\right)^{2} y}{\left(\frac{1}{2}\right)^{3}+1} \\
=0,2222 y \\
R(2,1)=T_{1}=\frac{0,25000000 y}{2} \\
+\left(\frac{1}{2}\right) 0,2222222 y \\
=0,23611111 y
\end{gathered}
$$

d. Menghitung integrasi pada baris kedua kolom kedua $R(2,2)$ :

$$
\begin{aligned}
& R(r, s)=\frac{4^{s-1} R(r, s-1)-R(r-1, s-1)}{4^{s-1}-1} \\
& R(2,2)=\frac{4^{2-1} R(2,2-1)-R(2-1,2-1)}{4^{2-1}-1} \\
&=\frac{4 R(2,1)-R(1,1)}{3} \\
&=\frac{4(0,23611111 y)-0,25000000 y}{3} \\
&=0,23158148 y
\end{aligned}
$$

Integral kedua yang diselesaikan adalah integral terhadap $y$ dengan fungsi $0.23158148 y$ :

1. Menentukan lebar interval $(h)$ pada batas $y$ :

$$
\begin{aligned}
h & =y_{2}-y_{1} \\
& =2-0 \\
& =2
\end{aligned}
$$

2. Menghitung integrasi pada kolom pertama $R(1,1)$ :

$$
\begin{gathered}
R(1,1)=T_{0}=\frac{h}{2}\left(f\left(x, y_{1}\right)+f\left(x, y_{2}\right)\right) \\
f\left(x, y_{1}\right)=f(x, 0)=0,23158158(0)=0 \\
f\left(x, y_{2}\right)=f(x, 2)=0,23158158(2) \\
=0,46296296 \\
R(1,1)=T_{0}=\frac{2}{2}(0+0,46296296) \\
=0,46296296
\end{gathered}
$$

3. Menghitung integrasi pada baris kedua kolom pertama $R(2,1)$ :

$$
\begin{aligned}
R(r, 1)=T_{k+1} & =\frac{T_{k}}{2}+\frac{h}{2^{k+1}} \sum_{j=1}^{2^{k}} f_{2 j-1}, f_{i} \\
& =f\left(y_{1}+i \frac{h}{2^{k+1}}\right), r \geq 2
\end{aligned}
$$

$$
\begin{gathered}
R(2,1)=T_{1}=\frac{T_{0}}{2}+\frac{h}{2} f_{1} \\
f_{1}=f\left(y_{1}+\frac{h}{2}\right)=f\left(0+\frac{2}{2}\right)=f(1) \\
=0,23148148(1) \\
=0,23148148 \\
R(2,1)=T_{1}=\frac{0,46296296}{2} \\
+\left(\frac{2}{2}\right) 0,23148148 \\
=0,46296296
\end{gathered}
$$

e. Menghitung integrasi pada baris kedua kolom kedua $R(2,2)$ :

$$
\begin{aligned}
R(2,2) & =\frac{4^{2-1} R(2,2-1)-R(2-1,2-1)}{4^{2-1}-1} \\
& =\frac{4 R(2,1)-R(1,1)}{4-1} \\
& =\frac{4(0,46296296)-0,46296296}{3} \\
& =0,46296296
\end{aligned}
$$

a. Untuk iterasi $\boldsymbol{n}=\mathbf{4}$ :

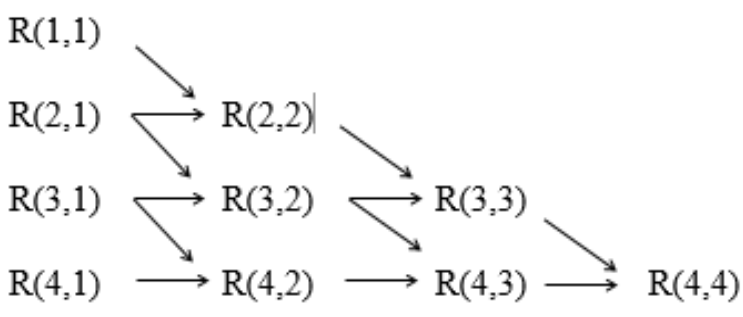

Menyelesaikan integral pertama terhadap $x$

1. Menentukan lebar interval $(h)$ pada batas $x$ :

$$
\begin{aligned}
h & =x_{2}-x_{1} \\
& =1-0 \\
& =1
\end{aligned}
$$

2. Menghitung integrasi pada kolom pertama $R(1,1)$ :

$$
\begin{aligned}
R(1,1)=T_{0}= & \frac{h}{2}\left(f\left(x_{1}, y\right)\right. \\
& \left.+f\left(x_{2}, y\right)\right) \\
f\left(x_{1}, y\right)=f(0, y) & =f(0)=0 \\
f\left(x_{2}, y\right)=f(1, y) & =f(1) \\
& =0,50000000 y
\end{aligned}
$$

$$
\begin{aligned}
R(1,1)=T_{0} & =\frac{1}{2}(0+0,50000000 y) \\
& =\frac{1}{4} y \\
& =0,25000000 y
\end{aligned}
$$

3. Menghitung integrasi pada baris kedua kolom pertama $R(2,1)$ : 


$$
\begin{gathered}
R(r, 1)=T_{k+1}=\frac{T_{k}}{2}+\frac{h}{2^{k+1}} \sum_{j=1}^{2^{k}} f_{2 j-1}, f_{i} \\
=f\left(x_{1}+i \frac{h}{2^{k+1}}\right), r \geq 2 \\
R(2,1)=T_{1}=\frac{T_{0}}{2}+\frac{h}{2} f_{1} \\
f_{1}=f\left(x_{1}+\frac{h}{2}\right)=f\left(0+\frac{1}{2}\right)=f\left(\frac{1}{2}\right) \\
=\frac{\left(\frac{1}{2}\right)^{2} y}{\left(\frac{1}{2}\right)^{3}+1} \\
=0,22222222 y \\
R(2,1)=T_{1}=\frac{0,25000000 y}{2} \\
+\left(\frac{1}{2}\right) 0,22222222 y \\
=0,23611111 y
\end{gathered}
$$

4. Menghitung integrasi pada baris ketiga kolom pertama $R(3,1)$ :

$$
\begin{aligned}
& R(r, 1)=T_{k+1}= \frac{T_{k}}{2}+\frac{h}{2^{k+1}} \sum_{j=1}^{2^{k}} f_{2 j-1}, f_{i} \\
&= f\left(x_{1}+i \frac{h}{2^{k+1}}\right), r \geq 2 \\
& R(3,1)=T_{2}=\frac{T_{1}}{2}+\frac{h}{4}\left(f_{1}+f_{3}\right) \\
& f_{1}=f\left(x_{1}+\frac{h}{4}\right)=f\left(0+\frac{1}{4}\right)=f\left(\frac{1}{4}\right) \\
&=\frac{\left(\frac{1}{4}\right)^{2} y}{\left(\frac{1}{4}\right)^{3}+1} \\
&=0.06153846 y \\
&\left.\begin{array}{rl}
3 h \\
4
\end{array}\right)=f\left(0+\frac{3}{4}\right)=f\left(\frac{3}{4}\right) \\
&=\frac{\left(\frac{3}{4}\right)^{2} y}{\left(\frac{3}{4}\right)^{3}+1} \\
&=0,39560439 y \\
&=\frac{0,23611111 y}{2} \\
&+\frac{1}{4}(0,06153846 y \\
&+0,39560439 y) \\
&=0,23234127 y \\
& R(3,1)=T_{2} y
\end{aligned}
$$

5. Menghitung integrasi pada baris keempat kolom pertama $R(4,1)$ :

$$
\begin{array}{r}
R(r, 1)=T_{k+1} \\
=\frac{T_{k}}{2}+\frac{h}{2^{k+1}} \sum_{j=1}^{2^{k}} f_{2 j-1}, f_{i} \\
=f\left(x_{1}+i \frac{h}{2^{k+1}}\right), r \geq 2 \\
R(4,1)=T_{3}=\frac{T_{2}}{2} \\
+\frac{h}{8}\left(f_{1}+f_{3}+f_{5}+f_{7}\right) \\
f_{1}=f\left(x_{1}+\frac{h}{8}\right)=f\left(0+\frac{1}{8}\right)=\frac{\left(\frac{1}{8}\right)^{2} y}{\left(\frac{1}{8}\right)^{3}+1}
\end{array}
$$$$
=0,01559454 y
$$$$
f_{3}=f\left(x_{1}+\frac{3 h}{8}\right)=f\left(0+\frac{3}{8}\right)=f\left(\frac{3}{8}\right)
$$$$
=\frac{\left(\frac{3}{8}\right)^{2} y}{\left(\frac{3}{8}\right)^{3}+1}
$$$$
=0,13358070 y
$$$$
f_{5}=f\left(x_{1}+\frac{5 h}{8}\right)=f\left(0+\frac{5}{8}\right)=f\left(\frac{5}{8}\right)
$$$$
=\frac{\left(\frac{5}{8}\right)^{2} y}{\left(\frac{5}{8}\right)^{3}+1}
$$$$
=0,31397174 y
$$$$
f_{7}=f\left(x_{1}+\frac{7 h}{8}\right)=f\left(0+\frac{7}{8}\right)
$$$$
=f\left(\frac{7}{8}\right)=\frac{\left(\frac{7}{8}\right)^{2} y}{\left(\frac{7}{8}\right)^{3}+1}
$$$$
=0,45847953 y
$$$$
R(4,1)=T_{3}=\frac{0,2323 y}{2}
$$$$
+\frac{1}{8}(0,01559454 y
$$$$
+0,13358070 y+
$$$$
0,31397174 y
$$$$
+0,45847953)
$$$$
=0,23137395 y
$$

6. Menghitung integrasi pada baris kedua kolom kedua $R(2,2)$ :

$$
\begin{aligned}
& R(r, s)=\frac{4^{s-1} R(r, s-1)-R(r-1, s-1)}{4^{s-1}-1} \\
& R(2,2)=\frac{4^{2-1} R(2,2-1)-R(2-1,2-1)}{4^{2-1}-1}
\end{aligned}
$$




$$
\begin{aligned}
& =\frac{4 R(2,1)-R(1,1)}{3} \\
& =\frac{4(0,23611111 y)-0,25000000 y}{3} \\
& =0,231488148 y
\end{aligned}
$$

$$
\begin{aligned}
& =\frac{4 R(3,1)-R(2,1)}{3} \\
R(3,2) & =\frac{4(0,23234127 y)-0,23611111 y}{3} \\
& =0,23108466 y
\end{aligned}
$$

7. Menghitung integrasi pada baris ketiga kolomengan cara/formula yang sama, hasil kedua $R(3,2)$ :

$R(3,2)=\frac{4^{2-1} R(3,2-1)-R(3-1,2-1)}{4^{2-1}-1}$ perhitungan untuk baris dan kolom yang lain dapat dilihat pada table 1 berikut.

Tabel 1 Hasil integrasi Romberg terhadap $x$

\begin{tabular}{|c|c|c|c|c|}
\hline $\mathrm{R}(\mathrm{r}, \mathrm{s})$ & 1 & 2 & 3 & 4 \\
\hline 1 & $0.25000000 \mathrm{y}$ & & & \\
\hline 2 & $0.23611111 \mathrm{y}$ & $0.23148148 \mathrm{y}$ & & \\
\hline 3 & $0.23234127 \mathrm{y}$ & $0.23108466 \mathrm{y}$ & $0.23105820 \mathrm{y}$ & \\
\hline 4 & $0.23137395 \mathrm{y}$ & $0.23105151 \mathrm{y}$ & $0.23104930 \mathrm{y}$ & $\mathbf{0 . 2 3 1 0 4 9 1 6} \mathbf{y}$ \\
\hline
\end{tabular}

Menyelesaikan integral kedua terhadap $y$ dengan fungsi $0.23104916 y$ :

1. Menentukan lebar interval $(h)$ pada batas $y$ :

$$
\begin{aligned}
h & =y_{2}-y_{1} \\
& =2-0 \\
& =2
\end{aligned}
$$

2. Menghitung integrasi pada kolom pertama $R(1,1)$ :

$$
\begin{gathered}
R(1,1)=T_{0}=\frac{h}{2}\left(f\left(x, y_{1}\right)+f\left(x, y_{2}\right)\right) \\
f\left(x, y_{1}\right)=f(x, 0)=0,23104916(0)=0 \\
f\left(x, y_{2}\right)=f(x, 2)=0,23104916(2) \\
=0,46209831 \\
R(1,1)=T_{0}=\frac{2}{2}(0+0,46209831) \\
=0,46209831
\end{gathered}
$$

3. Menghitung integrasi pada baris kedua kolom pertama $R(2,1)$ :

$$
\begin{aligned}
& R(r, 1)=T_{k+1}=\frac{T_{k}}{2}+\frac{h}{2^{k+1}} \sum_{j=1}^{2^{k}} f_{2 j-1}, f_{i} \\
& =f\left(y_{1}+i \frac{h}{2^{k+1}}\right), r \geq 2 \\
& R(2,1)=T_{1}=\frac{T_{0}}{2}+\frac{h}{2} f_{1} \\
& f_{1}=f\left(y_{1}+\frac{h}{2}\right)=f\left(0+\frac{2}{2}\right)=f(1) \\
& =0,23104916 \\
& =0,23104916
\end{aligned}
$$

$$
\begin{aligned}
R(2,1)=T_{1}= & \frac{0,46209831}{2} \\
& +\left(\frac{2}{2}\right) 0,23104916 \\
= & 0,46209831
\end{aligned}
$$

4. Menghitung integrasi pada baris ketiga kolom pertama $R(3,1)$ :

$$
\begin{aligned}
R(3,1)=T_{2}=\frac{T_{1}}{2}+\frac{h}{2^{2}}\left(f_{1}+f_{3}\right) & \\
f_{1}= & f\left(y_{1}+\frac{h}{2^{2}}\right)=f\left(0+\frac{2}{4}\right) \\
= & 0,23104916\left(\frac{1}{2}\right) \\
= & 0,11552458 \\
f_{3}= & f\left(y_{1}+3 \frac{h}{2^{2}}\right)=f\left(0+3 \frac{2}{4}\right) \\
= & 0,23104916\left(\frac{3}{2}\right) \\
= & 0,34657374 \\
R(3,1)= & T_{2}=\frac{0,46209831}{2} \\
& +\frac{2}{4}(0,11552458 \\
& +0,34657374) \\
= & 0,46209831
\end{aligned}
$$

5. Menghitung integrasi pada baris keempat kolom pertama $R(4,1)$ :

$$
R(4,1)=T_{3}=\frac{T_{2}}{2}+\frac{h}{2^{3}}\left(f_{1}+f_{3}+f_{5}+f_{7}\right)
$$




$$
\begin{array}{r}
f_{1}=f\left(y_{1}+\frac{h}{2^{3}}\right)=f\left(0+\frac{2}{8}\right) \\
=0,23104916\left(\frac{1}{4}\right) \\
f_{1}=0,05776229 \\
f_{3}=f\left(y_{1}+3 \frac{h}{2^{3}}\right)=f\left(0+3 \frac{2}{8}\right) \\
=0,23104916\left(\frac{3}{4}\right) \\
=0,17328687 \\
f_{5}=f\left(y_{1}+5 \frac{h}{2^{3}}\right)=f\left(0+5 \frac{2}{8}\right) \\
=0,23104916\left(\frac{5}{4}\right) \\
=0,28881145 \\
\left.=0, \frac{h}{2^{3}}\right)=f\left(0+7 \frac{2}{8}\right) \\
=0,23104916\left(\frac{7}{4}\right) \\
f_{7}=f\left(y_{1}+40433603\right.
\end{array}
$$

$$
\begin{aligned}
R(4,1)=T_{3}= & \frac{0,46209831}{2} \\
& +\frac{2}{8}(0,05776229 \\
& +0,17328687+ \\
& 0,28881145+0,40433603) \\
& =0,46209831
\end{aligned}
$$

6. Menghitung integrasi pada baris kedua kolom kedua $R(2,2)$ :

$$
\begin{aligned}
R(r, s) & =\frac{4^{s-1} R(r, s-1)-R(r-1, s-1)}{4^{s-1}-1} \\
R(2,2) & =\frac{4^{2-1} R(2,2-1)-R(2-1,2-1)}{4^{2-1}-1} \\
& =\frac{4 R(2,1)-R(1,1)}{4-1} \\
& =\frac{4(0,46209831)-0,46209831}{3} \\
& =0,46209831
\end{aligned}
$$

Dengan cara/formula yang sama, hasil perhitungan untuk baris dan kolom yang lain dapat dilihat pada table 2 berikut:

Tabel 2 Hasil integrasi Romberg terhadap y

\begin{tabular}{|c|c|c|c|c|}
\hline $\mathrm{R}(\mathrm{r}, \mathrm{s})$ & 1 & 2 & 3 & 4 \\
\hline 1 & 0,46209831 & & & \\
\hline 2 & 0,46209831 & 0,46209831 & & \\
\hline 3 & 0,46209831 & 0,46209831 & 0,46209831 & \\
\hline 4 & 0,46209831 & 0,46209831 & 0,46209831 & 0,46209831 \\
\hline
\end{tabular}

\section{Metode Simulasi Monte Carlo}

a. Fungsi integran yang didefinisikan adalah $\frac{x^{2} y}{x^{3}+1}$

b. Batas bawah daerah integrasi $x_{1}=0$ batas atas daerah integrasi $x_{2}=1$

Batas bawah daerah integrasi $y_{1}=0$ batas atas daerah integrasi $y_{2}=2$

c. Untuk iterasi $\boldsymbol{n}=\mathbf{2}$

Integral pertama yang diselesaikan adalah integral terhadap $x$ :

1) Membangkitkan 2 buah data $\left(x_{i}\right)$ dari 0 sampai 1 pada Matlab

Misalkan $x_{i}=0,7431 \quad 0,3922$

2) Mensubstitusikan masing-masing nilai $x_{i}$ pada fungsi integran:

$$
\begin{aligned}
& x_{1}=\frac{0,7431^{2} y}{0,7431^{3}+1}=0,39153564 y \\
& x_{2}=\frac{0,3922^{2} y}{0,3922^{3}+1}=0,14506904 y
\end{aligned}
$$

3) Menjumlahkan nilai $x_{i}$ :

$$
\begin{aligned}
\sum_{i=0}^{2} x_{i} & =0,39153564 y+0,14506904 y \\
& =0,53660468 y
\end{aligned}
$$

4) Menghitung nilai integrasi $I$ :

$$
\begin{aligned}
I & =\frac{b-a}{n} \sum_{i=0}^{n} x_{i} \\
& =\frac{1-0}{2} x 0,53660468 y \\
& =0,26830234 y
\end{aligned}
$$

Integral kedua yang diselesaikan adalah integral terhadap y dengan fungsi integran berubah menjadi $0.26830234 y$.

1) Membangkitkan 2 buah data $\left(y_{i}\right)$ dari 0 sampai 2 pada Matlab

Misalkan $y_{i}=1,3110 \quad 0,3424$

2) Mensubstitusikan masing-masing nilai $y_{i}$ pada fungsi integran: 


$$
\begin{gathered}
y_{1}=0,2683 y=0,26830234(1,3110) \\
=0,34174438 \\
y_{2}=0,2683 y=0,26830234(0,3424) \\
=0,09186672
\end{gathered}
$$

3) Menjumlahkan nilai $y_{i}$ :

$$
\begin{aligned}
\sum_{i=0}^{2} y_{i} & =0,34174438+0,09186672 \\
& =0,44361109
\end{aligned}
$$

4) Menghitung nilai integrasi $I$ :

$$
\begin{aligned}
I & =\frac{d-c}{n} \sum_{i=0}^{n} y_{i} \\
& =\frac{2-0}{2} \times 0,44361109 \\
& =0,44361109
\end{aligned}
$$

Maka diperoleh solusi akhir untuk $n=2$ yaitu

\section{0,44361109}

d. Untuk iterasi $\boldsymbol{n}=\mathbf{4}$

Integral pertama yang diselesaikan adalah integral terhadap $x$

1) Membangkitkan 4 buah data $\left(x_{i}\right)$ dari 0 sampai 1 pada Matlab

Misalkan

$$
x_{i}=0,1269 \quad 0,7131 \quad 0,2706 \quad 0,8381
$$

2) Mensubstitusikan masing-masing nilai $x_{i}$ pada fungsi integran:

$$
\begin{aligned}
& x_{1}=\frac{0,1269^{2} y}{0,1269^{3}+1}=0,01607077 y \\
& x_{2}=\frac{0,7131^{2} y}{0,7131^{3}+1}=0,37318676 y \\
& x_{3}=\frac{0,2706^{2} y}{0,2706^{3}+1}=0,07180164 y \\
& x_{4}=\frac{0,8381^{2} y}{0,8381^{3}+1}=0,44213225 y
\end{aligned}
$$

3) Menjumlahkan nilai $x_{i}$ :

$$
\begin{aligned}
\sum_{i=0}^{4} x_{i}= & 0,01607077 y+0,37318676 y+ \\
& 0,07180164 y+0,44213225 y \\
& =0,90319143 y
\end{aligned}
$$

4) Menghitung nilai integrasi $I$ :

$$
\begin{aligned}
I & =\frac{b-a}{n} \sum_{i=0}^{n} x_{i} \\
I & =\frac{1-0}{4} \times 0,90319143 y \\
& =0,22579786 y
\end{aligned}
$$

Integral kedua yang diselesaikan adalah integral terhadap y dengan fungsi integran berubah menjadi $0.22579786 y$.

1) Membangkitkan 4 buah data $\left(y_{i}\right)$ dari 0 sampai 2 pada Matlab

Misalkan

$y_{i}=0,2279 \quad 1,2123 \quad 1,3451 \quad 1,1745$

2) Mensubstitusikan masing-masing nilai $y_{i}$ pada fungsi integran:

$$
\begin{aligned}
y_{1} & =0,22579786 y \\
& =0,22579786(0,2279)=0,05145933 \\
y_{2} & =0,22579786 y \\
& =0,22579786(1,2123)=0,27373474 \\
y_{3} & =0,22579786 y \\
& =0,22579786(1,3451)=0,30372070 \\
y_{4} & =0,22579786 y \\
& =0,22579786(1,1745)=0,26519958
\end{aligned}
$$

3) Menjumlahkan nilai $y_{i}$ :

$$
\begin{aligned}
\sum_{i=0}^{4} y_{i}= & 0,05145933+0,27373474+ \\
& 0,30372070+0,26519958 \\
= & 0,89411436
\end{aligned}
$$

4) Menghitung nilai integrasi $I$ :

$$
\begin{aligned}
I & =\frac{d-c}{n} \sum_{i=0}^{n} y_{i} \\
& =\frac{2-0}{4} \times 0,89411436 \\
& =0,44705718
\end{aligned}
$$

Maka diperoleh solusi akhir untuk $n=4$ yaitu

\section{0,44705718}

\section{Perhitungan Galat}

\section{Metode Romberg}

Galat mutlak dari metode Romberg yaitu sebagai berikut:

1) untuk $n=2$

$$
\begin{aligned}
\varepsilon & =\left|I-I^{\prime}\right| \\
& =|0,46209812-0,46296296| \\
& =0,00086484
\end{aligned}
$$

2) untuk $n=4$

$$
\begin{aligned}
\varepsilon & =\left|I-I^{\prime}\right| \\
& =|0.46209812-0,46209831| \\
& =0,00000019
\end{aligned}
$$

\section{Metode Simulasi Monte Carlo}

Galat mutlak dari metode Simulasi Monte Carlo yaitu sebagai berikut:

1) untuk $n=2$ 


$$
\begin{aligned}
\varepsilon & =\left|I-I^{\prime}\right| \\
& =|0,46209812-0,44361109| \\
& =0,01848703
\end{aligned}
$$

2) untuk $n=4$

$$
\begin{aligned}
\varepsilon & =\left|I-I^{\prime}\right| \\
& =|0,46209812-0,44705718| \\
& =0,01499812
\end{aligned}
$$

Selanjutnya disimulasikan beberapa fungsi aljabar rasional dan irrasional dalam program Matlab. Perbandingan galat dari kedua metode tersebut dapat dilihat pada tabel 1 Apendiks. Pada tabel 1 apendiks terlihat bahwa untuk iterasi dalam jumlah kecil (2 dan 4), metode Simulasi Monte Carlo menghasilkan galat yang relatif lebih besar. Oleh karena itu perlu disimulasikan pula untuk iterasi dalam jumlah yang besar (1000 dan 10000). Seperti terlihat pada tabel 2 apendiks.

\section{KESIMPULAN}

Berdasarkan pembahasan yang telah dilakukan dapat disimpulkan bahwa pada penyelesaian integral lipat dua dengan fungsi aljabar yang berbentuk rasional dan irrasional, metode Romberg lebih akurat dibandingkan dengan metode Simulasi Monte Carlo. Hal ini dibuktikan dengan nilai galat mutlak yang dihasilkan metode Romberg jauh lebih kecil dibandingkan dengan metode Simulasi Monte Carlo. Dengan iterasi $n=4$, metode Romberg bisa menghasilkan galat sebesar 0.000000003 pada fungsi aljabar rasional dan 0.00000007 pada fungsi aljabar irrasional. Sedangkan pada metode Simulasi Monte Carlo untuk iterasi $n=10000$ sekalipun galat yang dihasilkan tidak lebih kecil dari galat yang dihasilkan metode Romberg.

\section{DAFTAR PUSTAKA}

Ammar, Muhammad. Solusi Penyelesaian Integral Lipat Dua dengan Menggunakan Metode Romber. Makassar: UIN Alauddin. 2009.

Ardi, Pujiyanta. Komputasi Numerik dengan Matlab. Yogyakarta: Graha Ilmu. 2007

Arhami, Muhammad dkk. Pemrograman MATLAB. Yogyakarta: ANDI, 2012.
Away, Gunaidi Abdia. the Shorcut of Matlab Programming. Bandung: Informatika Bandung, 2006.

Elhasany, Zain. Contoh Daftar Pustaka Makalah Dan Skripsi, Artikel Ilmiah Lengkap, diakses dari http://www.scribd.com/doc/92181730/M ETODE-NUMERIK\#scribd, pada tanggal 11 Oktober 2015 pukul 21.11

Haryono, Nugroho agus. Perhitungan Integral Lipat Menggunakan Metode Monte Carlo. Jurnal Informatika vol. 5 no. 2. Yogyakarta: Universitas Kristen Duta Wacana. 2009.

Hernadi, Julan. Matematika Numerik Dengan Implementasi MATLAB. Yogyakarta: ANDI. 2012.

Ilham, Muhammad. Modul 3 Integrasi Numerik. Bandung: Institut Teknologi Bandung. 2014.

Kosasih, Buyung. Komputasi Numerik Teori dan Aplikasinya. Yogyakarta: ANDI. 2006.

Munir, Rinaldi. Metode Numerik Revisi Kedua. Bandung: Informatika Bandung. 2008.

Munir, Rinaldi. Metode Numerik sebagai Algoritma

Komputasi.https://dirgamath29. files.wordpress.com.pdf (12 Mei 2015)

Sahid, Pengantar Komputasi Numerik dengan MATLAB. Yogyakarta: ANDI. 2005.

Sangadji, Metode Numerik. Yogyakarta: Graha Ilmu. 2008.

Setiawan, Agus. Pengantar Metode Numerik. Yogyakarta: ANDI. 2006.

Supangat, Andi. Matematika untuk Ekonomi dan Bisnis. Jakarta: Prenada Media Grup. 2006. 


\section{Apendiks}

Tabel 1. Perbandingan galat metode Romberg dan Simulasi Monte Carlo

\begin{tabular}{|c|c|c|c|c|c|}
\hline \multirow{2}{*}{ No } & \multirow{2}{*}{ Fungsi } & \multicolumn{2}{|c|}{ Galat Romberg } & \multicolumn{2}{|c|}{ Galat Simulasi Monte Carlo } \\
\hline & & $\mathrm{n}=2$ & $n=4$ & $n=2$ & $n=4$ \\
\hline 1 & $\int_{0}^{2} \int_{0}^{1} \frac{x^{6} y}{x^{7}+5} d x d y$ & 0,007623849 & 0,000008903 & 0,041656832 & 0,107791395 \\
\hline 2 & $\int_{0}^{4} \int^{2} \frac{x^{2} y}{x^{3}+1} d x d y$ & 0,003831037 & 0,000001352 & 0,22074213 & 0,058801476 \\
\hline 3 & $\int_{0}^{2} \int_{0}^{1} \frac{2 x^{3} y^{5}}{7 x^{4}+9} d x d y$ & 0,023547849 & 0,00002924 & 0,184802441 & 0,00197106 \\
\hline 4 & $\int_{0}^{2} \int_{0}^{1} \frac{5 x^{2} 9 y^{4}}{2 x^{3}-7} d x d y$ & 1,25674004 & 0,00071989 & 16,8500659 & 9,48896014 \\
\hline 5 & $\int_{-3}^{-1} \int_{-7}^{-5} \frac{x^{2} y}{x^{3}+1} d x d y$ & 0,000168037 & 0,000000003 & 0,306925181 & 0,220759238 \\
\hline 6 & $\int_{3}^{5} \int_{0}^{2} \frac{\left(x^{2}-2\right)^{2}}{y^{3}} d x d y$ & 0,01064197 & 0,00000022 & 0,05906214 & 0,02725182 \\
\hline 7 & $\int_{-3}^{0} \int_{-2}^{-1}\left(\frac{x-3}{y-2}\right)^{3} d x d y$ & 0,75158 & 0,0016 & 2,52229 & 4,78764 \\
\hline 8 & $\int^{1} \int^{1} x y(2+x)^{3} d x d y$ & 0,804166667 & 0,8 & 0,567868 & 0,541924 \\
\hline 9 & $\int_{0}^{2} \int_{0}^{1} \frac{\sqrt{x^{7} y^{5}}}{4} d x d y$ & 0,001959934 & 0,000001796 & 0,169797172 & 0,111395333 \\
\hline 10 & $\int_{2}^{5} \int_{1}^{3} \frac{\sqrt{x^{5} y^{3}}}{2} d x d y$ & 0,0241317 & 0,0000004 & 1,110119762 & 19,75899259 \\
\hline 11 & $\int_{0}^{2} \int_{0}^{1} \frac{\sqrt{5 x^{7} y^{2}}}{9} d x d y$ & 0,00167457 & 0,00000034 & 0,058711424 & 0,060424773 \\
\hline 12 & $\int_{0}^{2} \int_{0}^{1} \frac{\sqrt{3 x^{5} 9 y^{4}}}{-17} d x d y$ & 0,06650799 & 0,00000305 & 0,231671198 & 0,040737921 \\
\hline 13 & $\int_{1}^{3} \int_{0}^{2} y \sqrt{x^{2}+4} d y d x$ & 0,0010985 & 0,0000017 & 4,1471339 & 0,0056796 \\
\hline 14 & $\int_{2}^{4} \int_{0}^{2} \frac{y^{3}}{2 \sqrt{x+7}} d x d y$ & 0,0001922 & 0,000001 & 12,043452 & 6,8394404 \\
\hline 15 & $\int_{0}^{1} \int_{0}^{1} \frac{6 x y}{\sqrt[3]{3 x-1}} d x d y$ & 0,678661 & 0,625537 & 0,394852 & 0,062759 \\
\hline
\end{tabular}


JURNAL MSA VOL. 5 NO. 1 ED. JAN-JUNI 2017

tabel 2. Simulasi Monte Carlo untuk $n=1000$ dan $n=10000$

\begin{tabular}{|c|c|c|c|c|c}
\hline \multirow{2}{*}{ No. } & \multirow{2}{*}{ Fungsi } & \multicolumn{2}{c|}{ Simulasi Monte Carlo } & \multicolumn{2}{c}{ Galat Simulasi Monte Carlo } \\
\cline { 3 - 6 } 1 & $\int_{1}^{3} \int_{0}^{2} y \sqrt{x^{2}+4} d y d x$ & 18,4260326 & 18,3993512 & 0,0613354 & 0,034654 \\
\hline 2 & $\int_{3}^{5} \int_{0}^{2} \frac{\left(x^{2}-2\right)^{2}}{y^{3}} d x d y$ & 0,13517045 & 0,13459302 & 0,00242971 & 0,00185228 \\
\hline 3 & $\int_{-3}^{0} \int_{-2}^{-1}\left(\frac{x-3}{y-2}\right)^{3} d x d y$ & 9,62460 & 9,59395 & 0,06165 & 0,09230 \\
\hline 4 & $\int_{2}^{4} \int_{0}^{2} \frac{y^{3}}{2 \sqrt{x+7}} d x d y$ & 21,6917663 & 21,2989075 & 0,4368449 & 0,0439861 \\
\hline
\end{tabular}

